\title{
Pengaruh Anggaran Kas terhadap Tingkat Likuiditas pada Perusahaan Property dan Real Estate di Jakarta Islamic Index (JII) Periode 2015-2017
}

\author{
Siti Fauzun \\ Prodi Akintansi Syariah, Fakultas Ekonomi dan Bisnis Islam, IAIN Madura Indonesia \\ siti_fauzun@gmail.com \\ Fatati Nuryana \\ Prodi Perbankan Syariah, Fakultas Ekonomi dan Bisnis Islam, IAIN Madura Indonesia, \\ fnuryana@gmail.com
}

\begin{abstract}
:
The importance of a cash budget is to maintain a liquidity position and to find out the cash deficit or surplus, where a cash budget is an estimate of the cash position of a certain period in the future regarding cash receipts and cash disbursements. The level of liquidity is an important factor because the level of liquidity of a company reflects the ability of a company to pay short-term liabilities (current debt) at maturity using current assets. The problem raised by the author is whether the cash budget affects the level of liquidity in property and real estate companies for the period 2015-2017 and how much does the cash budget contribute to the level of liquidity in property and real estate companies listed in the Jakarta Islamic Index. This research is a quantitative study. with one independent variable and one dependent variable. The population in this study were property and real estate companies listed on the Jakarta Islamic Index for the period 2015-2017. The research sample of 11 companies obtained by saturated sampling technique and using simple linear regression analysis techniques. The type of data used is secondary data. The results showed that the cash budget had no significant effect on liquidity. This is because the value of the Quick Ratio (QR) in property and real estate companies listed on the Jakarta Islamic Index (JII) is relatively small, around the number 50 and below. This is evident from the results of the test which shows t count> $t$ table which is equal to $1.593>1.695$. And the significant value of variable $X$ (cash budget) is above 0.05 , namely $0.121>0.05$. The coefficient of determination (R2) in this study shows that the R Square column is 0.076 . This means that the contribution of cash budget costs to the level of liquidity of property and real estate companies in the Jakarta Islamic Index (JII) $2015-2017$ is $7.6 \%$, while the remaining $92.4 \%$ is the contribution of other variables that are not taken into account. in this research. The results of statistical tests do not show a significant relationship or difference in the data tested, because the Quick Ratio in the property and real estate sector companies is relatively small, around the number 50 and below, some are even below 0 and there are only a few that have a high quick ratio of 11 companies.
\end{abstract}

Keyword: Cash Budget; Quick Ratio (QR)

\section{ABSTRAK :}

Pentingnya suatu anggaran kas untuk menjaga posisi likuiditas dan untuk mengetahui defisit atau surplus kas, dimana suatu anggaran kas merupakan estimasi posisi kas periode tertentu dimasa mendatang tentang penerimaan kas dan tentang pengeluaran kas. Tingkat likuiditas merupakan salah satu faktor penting karena tingkat likuiditas suatu perusahaan menggambarkan kemampuan suatu perusahaan membayar kewajiban jangka pendek (utang lancar) pada saat jatuh tempo dengan menggunakan 
aktiva lancar. Permasalahan yang diangkat oleh penulis adalah apakah anggaran kas berpengaruh terhadap tingkat likuiditas pada perusahaan property dan real estate periode 2015-2017 dan seberapa besar kontribusi anggaran kas terhadap tingkat likuiditas pada perusahaan property dan real estate yang terdaftar di Jakarta Islamic Index.Penelitian ini merupakan penelitian kuantitatif dengan satu variabel independen dan satu variabel dependen. Populasi dalam penelitian ini adalah perusahaan property dan real estate yang terdaftar di Jakarta Islamic Index periode 2015-2017. Sampel penelitian sebanyak 11 perusahaan yang diperoleh dengan teknik sampling jenuh dan menggunakan teknik analisis regresi linear sederhana. Jenis data yang digunakan adalah data sekunder.Hasil penelitian menunjukkan bahwa anggaran kas tidak berpengaruh berpengaruh signifikan terhadap likuiditas. Hal ini disebabkan karena nilai Quick Ratio (QR) Pada perusahaan property dan real estate yang terdaftar di Jakarta Islamic Index (JII) relatif kecil berada disekitar angka 50 kebawah. Hal ini terbukti dilihat dari hasil uji $t$ menunjukkan $t_{\text {hitung }}>t_{\text {tabel }}$ yaitu sebesar 1,593>1,695. Dan nilai signifikan dari variabel $X$ (anggaran kas) diatas 0,05 yaitu 0,121>0,05. Nilai koefisien determinasi $\left(\mathrm{R}^{2}\right)$ dalam penelitian ini menunjukkan bahwa pada kolom $\mathrm{R}$ Square adalah 0,076. Hal ini berarti bahwa besar kontribusi biaya anggaran kas terhadap tingkat likuiditas perusahaan Property dan real estate di Jakarta Islamic Index (JII) Tahun 2015-2017 adalah sebesar 7,6\%, sedangkan sisanya 92,4\% adalah kontribusi variabel-variabel lain yang tidak diperhitungakn dalam penelitian ini. Hasil uji statistik tidak menunjukkan ada hubungan atau perbedaan signifikan pada data yang di uji, disebabkan karena Quick Ratio pada perusahaan sektor property dan real estate relatif kecil berada disekitar angka 50 kebawah bahkan ada yang di bawah 0 dan hanya ada beberapa yang quick rationya yang tinggi dari 11 perusahaan.

Kata Kunci: Anggaran Kas; Quick Ratio (QR) 


\section{PENDAHULUAN}

Perusahaan didirikan oleh perorangan atau lembaga dengan tujuan mendapatkan keuntungan optimal dari kegiatan usaha yang dijalankan. Menjalankan kegiatan usaha, umumnya perusahaan memerlukan modal, memerlukan biaya untuk membiayai kegiatan usahanya, menambah cadangan, dan memenuhi kewajibankewajiban pembayaran lainnya. Menjalankan kegiatan operasi perusahaan tentunya tidak terlepas dari berbagai permasalahan yang dapat menghambat gerak kemajuan usahanya. Beberapa masalah timbul tidak hanya datang dari dalam perusahaan saja namun juga dari luar perusahaan. Salah satu masalah yang timbul di dalam perusahaan adalah tidak tersedianya dana kas yang mencukupi dalam mendukung usaha perusahaan sehingga menghambat aktivitasnya. ${ }^{1}$

Selain faktor tidak tersedianya dana kas yang mencukupi, penyebab perusahaan tidak bisa membayar kewajibannya tersebut merupakan masalah manajemen perusahaan dalam menjalankan usahanya. Manajer perlu membuat rencana kegiatan dalam upaya menentukan kas minimal dengan menyususn anggaran kas. Anggaran kas dapat membantu manajemen dalam mengatasi perubahan-perubahan yang dapat mempengaruhi posisi kas. Oleh karena itu, penyusunan anggaran kas bagi perusahaan samgat penting untuk menjaga tingkat likuiditas perusahaan.

Kas merupakan aset yang paling likuid, semakin besar kas yang dimiliki perusahaan maka akan semakin tinggi tingkat likuiditas, semakin tinggi tingkat kemampuan membayar jangka pendek (utang lancar). ${ }^{2}$ Jumlah kas relatif kecil akan mempertimbangkan putaran kas dan meningkatkan rentabilitas (meningkatkan kemampuan memperoleh laba) tetapi dengan kas yang kurang (terlalu kecil) dapat mengganggu kemampuan membayar (tidak likuid) sewaktu ada tagihan, yang pada akhirnya juga akan mengganggu rentabilitas. Dengan demikian kas mempunyai peranan penting dalam menentukan kelancaran kegiatan perusahaan. Oleh karena itu, kas harus direncanakan dan diawasi dengan baik arus kas masuk maupun arus kas keluar. ${ }^{3}$

Suatu perusahaan harus memiliki anggaran kas untuk menjaga posisi likuiditas dan untuk mengetahui defisit atau surplus kas. Anggaran kas ialah estimasi posisi kas periode tertentu dimasa mendatang tentang penerimaan kas dan tentang pengeluaran kas. Penerimaan kas itu pada umumnya dari modal pemilik, hutang, penjualan tunai, penerimaan piutang, penjualan aktiva tetap dan lain-lain. Sedangkan pengeluaran kas itu pada umumnya untuk pembelian aktiva tetap, pembelian bahan baku, pembayaran upah tenaga kerja langsung, pembayaran biaya tidak langsung pabrik, pembayaran biaya pemasaran, pembayaran biaya umum dan administrasi, pembayaran bunga, pembayaran deviden, pembayaran jasa produksi, pembayaran premi asuransi, pembayaran pajak dan pengeluaran lain-lain. ${ }^{4}$

Tingkat likuiditas suatu perusahaan merupakan salah satu faktor penting karena tingkat likuiditas suatu perusahaan menggambarkan kemampuan suatu

${ }^{l}$ Enik Septiyani, Siti Ragil Handayani, Muhammad Saifi'”Analisis Budget Kas dalam Meningkatkan Likuiditas dan Profitabilitas Perusahaan Kacang Tulungagung (Skripsi, Fakultas ilmu administrasi Universitas Brawijaya Malang), hlm. 1 (diakses pada tanggal 19 april 2018)

${ }^{2}$ M Nafarin, Penganggaran Perusahaan Edisi 3, (Jakarta: Salemba Empat,2017), hlm. 308

${ }^{3}$ Ibid, hlm. 309

${ }^{4}$ Darsono Prawironegoro, Ari Purwanto, Penganggaran Perusahaan Edisi 2 (Jakarta: Mitra Wacana Media,2010), hlm. 107 
perusahaan membayar kewajiban jangka pendek (utang lancar) pada saat jatuh tempo dengan menggunakan aktiva lancar. ${ }^{5}$

Perusahaan properti adalah perusahaan yang bergerak di bidang kepemilikan harta yang berbentuk tanah dan bangunan beserta sarana dan prasarana yang ada di dalamnya sebagai elemen yang tidak terpisahkan. Seperti halnya pusat perbelanjaan, hotel, gedung perkantoran, rumah sakit dll. ${ }^{6}$

Perusahaan properti memiliki prospek yang cerah di masa yang akan datang dengan melihat potensi jumlah penduduk yang terus bertambah besar. Perkembangan industry property dan real estate saat ini menunjukkan pertumbuhan yang sangat meyakinkan. Hal ini ditandai dengan maraknya pembangunan perumahan, apartemen perkantoran, ruko dan pusat perbelanjaan di kota-kota besar. Berdasarkan perspektif makro ekonomi, industri properti memiliki cakupan usaha yang amat luas sehingga bergairahnya bisnis properti akan berpengaruh terhadap pertumbuhan ekonomi. ${ }^{7}$

Pertumbuhan sektor property dan real estate tentu saja akan tetap menarik minat para investor dikarenakan harga tanah dan bangunan yang cenderung terus naik, penawaran tanah bersifat tetap sedangkan permintaan selalu bertambah besar seiring dengan pertambahan jumlah penduduk serta bertambahnya kebutuhan manusia setiap tahunnya. ${ }^{8}$

Namun masalahnya dalam penelitian sebelumnya ada ketidakkonsistenan mengenai berpengaruh atau tidaknya suatu anggaran kas terhadap tingkat likuiditas seperti halnya penelitian yang diteliti oleh Suci Siti Nurfadillah, 2016 hasil penelitiannya menunjukkan bahwa Faktor Anggran Kas memberikan pengaruh tetapi tidak signifikan dan negatif terhadap tingkat likuiditas. ${ }^{9}$

Dalam penelitian sebelumnya penelitian yang diteliti oleh Febby Fabiola Adyana Poetri menyatakan bahwa anggaran kas berpengaruh namun tidak signifikan terhadap

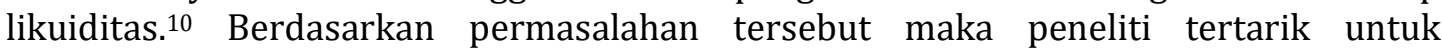
melakukan penelitian dengan judul "Pengaruh Anggaran Kas terhadap Tingkat Likuiditas Pada Perusahaan Propeti di Jakarta Islamic Index Periode 2015-2017"

Berdasarkan latar belakang masalah, dan batasan masalah diatas, maka penelitian ini dirumuskan sebagai berikut :

\footnotetext{
${ }^{5}$ Dermawan Syahrial, Djahotman Purba, Analisis Laporan Keuangan (Jakarta: Mitra Wacana Media,2013), hlm. 37

${ }^{6}$ https:www.sahamok.com/beda-real-estate-dengan-properti.(diakses pada tanggal 25 oktober 2018 jam :09.00)

${ }^{7}$ Mulyawati Wijaya, Analisis Praktik Perataan Laba Pada Industri Real Estate dan Property Yang Bereputasi Baik di Bursa Efek Indonesia. Jurnal Akuntansi Kontemporer, Vol. 1. No , juli 2009, hlm. 185

${ }^{8}$ Febrianty Wulandari, Kinerja Keuangan Perusahaan Property dan Real Estate di BEI Selama Periode 2012-2016 yang Termasuk di Indeks LQ45 (Studi Kasus pada Perusahaan yang Termasuk Pemeringkatan Indeks LQ45 Periode Februari 2017- juli 2017), Jurnal Manajemen dan Bisnis Sriwijaya Vol. 15 (1), 2017, hlm. 1

${ }^{9}$ Suci Siti Nurfadillah, Pengaruh Anggaran Kas sebagai Alat Perencanaan dan Alat Pengendalian terhadap Tingklat Likuiditas, Pada Koperasi Bina Raharja Kuningan KCP Luragung. (Skripsi Fakultas syariah dan ekonomi islam IAIN Syekh Nurjati Cirebon), hlm. 1

${ }^{10}$ Febby Febiola Adyana Poetri, Pengaruh Anggaran Kas Terhadap Likuiditas Serta Dampaknya Terhadap Laba Operasional (Study kasus Pada PT.BPR POLA DANA Tasikmaya), Skripsi fakultas ekonomi jurusan Akuntansi Universitas Siliwangi Tasikmalya, hlm. 1-2
} 
Apakah anggaran kas berpengaruh terhadap tingkat likuiditas pada perusahaan property dan real estate periode 2015-2017?

Seberapa besar kontribusi anggaran kas terhadap tingkat likuiditas pada perusahaan property dan real estate periode 2015-2017?

\section{Pengertian Manajemen keuangan}

Manajemen keuangan adalah keseluruhan aktivitas yang bersangkutan dengan usaha untuk mendapatkan dana tersebut secara efisien. ${ }^{11}$ Dengan kata lain manajemen keuangan adalah segala aktivitas yang berhubungan dengan perolehan, pendanaan, dan pengolahan aktiva dengan beberapa tujuan menyeluruh. Yang meliputi fungsi dan tanggung jawab para manajer keuangan, di mana tugas pokok manajer keuangan adalah merencanakan untuk memperoleh dana dan menggunakan dana tersebut untuk memaksimalkan nilai perusahaan.

\section{Fungsi dan tanggung jawab manajer keuangan}

Manajer keuangan mempunyai tanggung jawab yang besar terhadap apa yang telah dilakukannya. Adapun keputusan keuangan yang menjadi tanggung jawab manajer keuangan dikelompokkan kedalam 3 jenis: ${ }^{12}$

Mengambil keputusan investasi (investmen decision).

Mengambil keputusan pembelanjaan (financing decision)

Mengambil keputusan dividen (dividend decision)

Secara umum kegiatan utama atau fungsi keuangan terbagi dua kelompok: ${ }^{13}$

Kegiatan mencari dana (obtain of fund)

Kegiatan menggunakan dana (alocation of fun)

Fungsi manajemen keuangan syari'ah: ${ }^{14}$

Keputusan investasi

Keputusan pendanaan

Keputusan bagi hasil atau deviden

Keputusan zakat perusahaan.

\section{Tujuan manajemen keuangan}

Tujuan manajemen keuangan adalah memaksimumkan kemakmuran pemegang saham atau memaksimumkan nilai perusahaan, bukan memaksimumkan profit. Arti memaksimumkan profit berarti mengabaikan tanggung jawab sosial, mengabaikan resiko, dan berorientasi jangka pendek. Sedangkan arti memaksimumkan kemakmuran pemegang saham atau nilai perusahaan sebagai berikut: 15

Berarti memaksimumkan nilai sekarang (present value) semua keuntungan di masa datang yang akan diterima oleh pemilik perusahaan.

Berarti lebih menekankan pada aliran hasil bukan sekedar laba bersih dalam pengertian akuntansi. Kelebihan tujuan memaksimumkan nilai perusahaan/ kemakmuran

${ }^{11}$ Anang Fakhroji, Pengantar Manajemen Keuangan ( Klanten : Yayasan Humaniora, 2010), hlm. 4

12 Anang Fakhroji, Pengantar Manajemen Keuangan ( Klanten : Yayasan Humaniora, 2010), hlm. 1011

13 Asnaini; Evan Stiawan dan Windi Asriani; Manajemen Keuangan (Yogyakarta: Teras, 2012), hlm. 2

${ }^{14}$ Muhamad, Manajemen Keuangan Syari'ah Analisis Fiqh dan Keuangan (Yogyakarta: UPP STIM YKPN, 2016, hlm. 8

15 Anang Fakhroji, hlm.12 
pemegang saham adalah secara konseptual jelas sebagai pedoman di dalam pengambilan keputusan yang mempertimbangkan faktor risiko.

\section{Pengertian Anggaran Kas}

Aggaran kas disebut juga dengan anggaran perubahan kas dan ada juga yang menyebut dengan anggaran sumber dan penggunaan kas, tetapi sebaiknya disebut anggaran sumber dan belanja kas atau anggaran masuk dan anggaran keluar. ${ }^{16}$

Kas merupakan asset yang paling likuid, semakin besar kas yang dimiliki perusahaan, maka semakin tinggi tingkat likuiditas, semakin tinggi tingkat kemampuan membayar kewajiban jangka pendek (utang lancar). Kas adalah uang yang siap dan bebas digunakan. Anggaran kas ini bukan hanya menunjukkan jumlah keseluruhan pembelajaran diperlukan, tetapi juga kapan kas tersebut diperlukan. Anggaran kas ini menunjukkan jumlah kas yang diperlukan setiap bulan, setiap minggu bahkan setiap hari, merupakan alat manajer keuangan yang paling penting.

Anggaran kas adalah anggaran yang menunjukkan perubahan kas dan memberikan alasan mengenai perubahan kas tersebut dengan menunjukkan arus kas masuk sebagai sumber kas dan arus kas keluar sebagai arus kas dibelanjakan (digunakan) sehingga tampak kelebihan atau kekurangan kas, dan saldo kas selama periode tertentu dari suatu organisasi. ${ }^{17}$

\section{Jenis-jenis anggaran kas}

Anggaran kas biasanya terdiri dari 4 bagian utama; Bagian penerimaan (receipts section), yaitu saldo kas awal, penagihan kas dari pelanggan, dan penerimaan lainnya. Bagian pengeluaran, yang terdiri dari semua pembayaran kas yang dilakukan sesuai tujuan. Bagian surplus atau defisit kas yang hanya menunjukkan perbedaan antara bagian penerimaan kas dan bagian pengeluaran kas. Bagian pembiayaan yang memberikan catatan rinci mengenai pinjaman (borrowing) dan pelunasan yang diperkirakan terjadi selama periode anggaran. ${ }^{18}$

\section{Tujuan Penyusunan anggaran kas}

Tujuan utama penyusunan anggaran kas adalah merencanakan posisi likuiditas sebagai dasar untuk menentukan pinjaman dimasa datang dan investasi yang akan dilakukan.

Tujuan penyusunan anggaran kas antara lain; Menentukan saldo (posisi) kas akhir setiap periode sebagai hasil dari operasi yang dijalankan, mengetahui kelebihan (surplus) atau kekurangan (defisit) kas pada waktunya, menyelaraskan kas dengan asset lancar, asset tak lancar, utang, modal, dapatan, dan beban, mengetahui sumber kas masuk yang diperoleh selama satu periode dan digunakan untuk apa sumber kas masuk tersebut, hal ini tampak pada arus kas keluar, menilai realisasi kas masuk dan kas keluar agar dapat diketahui selisih realisasi dengan anggaran, selisih menguntungkan atau selisih merugikan, memperkirakan sumber kas masa akan datang dari arus kas masuk dan kemana kas tersebut digunakan dari arus kas keluar, menunjukkan

\footnotetext{
${ }^{16}$ M. Nafarin, Penganggaran Perusahaan Edisi 3 (Jakarta: Salemba Empat, 2017), hlm. 308

${ }^{17}$ Ibid, hlm.309

${ }^{18}$ Joe K. Shim;Joel G.Siegel, Budgeting (Jakarta : Erlangga, 2000), hlm.61
} 
hubungan laba bersih terhadap perubahan kas perusahaan biasanya laba bersih bergerak bersama. Tingginya tingkat laba menyebabkan peningkatan kas. ${ }^{19}$

\section{Faktor yang mempengaruhi anggaran kas}

Anggaran kas masuk dan anggaran kas keluar besar kecilnya dipengaruhi oleh faktor kegiatan perusahaan, yaitu kegiatan operasi, inverstasi dan pendanaan. ${ }^{20}$ Kegiatan operasi, Kegiatan investasi dan Kegiatan pendanaan.

\section{Pengertian rasio likuiditas}

Rasio likuiditas (liquidity ratio) adalah rasio yang bertujuan untuk mengetahui kemampuan perusahaan dalam membayar kewajiban jangka pendek.

\section{METODE PENELITIAN}

Rancangan penelitian bermakna strategis untuk mengatur latar (setting) penelitian agar dapat memperoleh data yang valid sesuai dengan karakteristik variabel dan tujuan penelitian. Jenis penelitian ini merupakan penelitian menggunakan pendekatan kuantitatif yaitu penelitan dengan memperoleh data yang berbentuk angka. Dengan menggunakan jenis kausal, yang bertujuan untuk menganalisis hubungan suatu variabel dengan variabel lainnya.

Variabel yang digunakan dalam penelitian ini di kelompokkan menjadi 2 : Variabel dependen yaitu variabel yang mempengaruhi atau yang menjadi akibat, karena adanya variabel bebas. Sedangkan dalam penelitian ini yang menjadi variabel dependen yaitu Tingkat Likuiditas (Y). ${ }^{21}$

Variabel independen yaitu variabel yang mempengaruhi atau yang menjadi sebab perubahannya atau timbulnya variabel dependen (terikat). ${ }^{22}$ Yang menjadi variabel independen dalam penelitian ini yaitu variabel X yaitu Anggaran Kas

\section{Populasi dan Sampel}

Populasi adalah kumpulan dari seluruh elemen atau individu-individu yang merupakan sumber informasi dalam suatu riset. ${ }^{23}$ Macam populasi antara lain adalah populasi terhingga dan tak terhingga. Adapun yang dimaksud dengan populasi terhingga adalah sekumpulan objek yang akan dijadikan sebagai bahan kajian penelitian yang jumlahnya tertentu. ${ }^{24}$

Sampel adalah bagian dari jumlah dan karakteristik yang dimiliki oleh populasi. 25 Sedangkan teknik yang digunakan dalam pengambilan sampel menggunakan metode sampling jenuh. Teknik sampling jenuh merupakan teknik penentuan sampel bila semua anggota populasi digunakan sebagai sampel ${ }^{26}$. Peneliti menggunakan metode

\footnotetext{
${ }^{19}$ M. Nafarin, Penganggaran Perusahaan Edisi 3 (Jakarta: Salemba Empat, 2017), hlm. 310

${ }^{20}$ M. Nafarin, Penganggaran Perusahaan Edisi 3 (Jakarta: Salemba Empat, 2017), hlm. 311

${ }^{21}$ Sugiono, Statistika untuk penelitian, (Bandung : Alfabeta, 2015), hlm. 4

${ }^{22}$ Ibid

${ }^{23}$ Sonny Sumarsono, Metode Riset Sumber Daya Manusia (Yogyakarta: Graha Ilmu, 2004), hlm. 50

${ }^{24}$ Andi Supangat,STATISTIKA : Dalam Kajian Deskriptif, Inferensi, dan Nonparametrik. (Jakarta : Prenadamedia Group, 2007), hlm. 3

${ }^{25}$ V Wiratna Sujarweni; Poly Endrayanto, Statistika Untuk Penelitian (Yogyakarta: Graha Ilmu,2012), hlm. 13

${ }^{26}$ Ibid, hlm. 16
} 
sampling jenuh sebab pada penelitian ini jumlah populasi relatif sedikit. Jadi sampel pada penelitian ini yaitu 11 perusahaaan yang terdaftar di JII.

\section{Instrumen penelitian}

Instrumen penelitian adalah alat yang digunakan peneliti untuk mengumpulkan data. ${ }^{27}$ Dalam penelitian ini menggunakan data sekunder yaitu data yang diperoleh dari pihak lain. Data sekunder biasanya berupa data yang telah tersedia. Data sekunder ini berupa laporan keuangan tahunan Perusahaan Property dan Real Estate di www.idx.co.id

\section{Teknik Pengumpulan Data}

Teknik pengumpulan data yang digunakan adalah dokumentasi yaitu suatu metode pengumpulan data dengan mempelajari mengklasifikasi, data perusahaan dengan menggunakan data sekunder yang ada diperusahaan berupa catatan-catatan laporan keuangan yang berhubungan dengan penelitian.

\section{Teknik Analisis data}

Teknik analisa data yang digunakan dalam penelitian ini yaitu :Mencari data mentah, Statistik deskriptif, Uji Asumsi Klasik dan Uji Hipotesis

\section{DESKRIPSI DAN HASIL ANALISIS Pembuktian Hipotesis}

Hipotesis dalam penelitian dengan judul "Pengaruh Anggaran Kas terhadap tingkat Likuiditas pada Perusahaan Property dan Real Estate di Jakarta Islamic Index (JII) periode 2015-2017" adalah sebagai berikut: Diduga X (Anggaran Kas) berpengaruh terhadap Y (likuiditas) pada perusahaan Property dan Real Estate di JII tahun 2015 2017, Diduga X (Anggaran Kas) kontribusinya terhadap Y (Likuiditas) lebih besar dari $60 \%$. Selanjutnya untuk membuktikan hipotesis tersebut dilakukan beberapa pengujian sebagai berikut:

\section{Uji t (Uji Parsial/Individual)}

Uji-t dilakukan untuk mengetahui adakah pengaruh antara variabel X (Anggaran Kas) dengan variabel Y (Likuiditas) dengan a $=0,05$, digunakan untuk menguji apakah nilai koefisien regresi mempunyai pengaruh yang signifikan terhadap variabel terikat. Pengujian ini menggunakan distribusi $t$ yaitu membandingkan antara $t_{\text {hitung }}$ dengan $t_{\text {tabel }}$ dan dengan menggunakan probalibilitas $0,05(\mathrm{a}=5 \%)$ yaitu membandingkan nilai a dengan nilai sig Hipotesis diuji dengan pengambilan keputusan jika t hitung $<\mathrm{t}$ tabel, maka $\mathrm{H}_{\mathrm{o}}$ diterima $\left(\mathrm{H}_{\mathrm{a}}\right.$ ditolak), tetapi jika $\mathrm{t}$ hitung $>\mathrm{t}$ tabel, maka $\mathrm{H}_{\mathrm{o}}$ ditolak dan menerima $H_{a}$. berikut hasil Uji-t dengan menggunakan SPSS versi 20.

\footnotetext{
${ }^{27}$ Tim Penyusun Pedoman Penulisan Karya ilmiah, Pedoman Penulisan Karya Ilmiah, (Pamekasan: STAIN Pamekasan, 2015), hlm. 14
} 
Tabel 1

Hasil Uji t

\begin{tabular}{|c|c|c|c|c|c|c|}
\hline \multirow[t]{2}{*}{ Model } & & \multicolumn{2}{|c|}{$\begin{array}{l}\text { Unstandardized } \\
\text { Coefficients }\end{array}$} & \multirow{2}{*}{$\begin{array}{c}\text { Standardized } \\
\text { Coefficients } \\
\text { Beta }\end{array}$} & \multirow[t]{2}{*}{$\mathrm{T}$} & \multirow[t]{2}{*}{ Sig. } \\
\hline & & B & Std. Error & & & \\
\hline 1 & $\begin{array}{l}\text { (Constant) } \\
\text { ANGGARAN KAS }\end{array}$ & $\begin{array}{r}-.066 \\
2.836 \mathrm{E}-015\end{array}$ & $\begin{array}{l}.147 \\
.000\end{array}$ & .010 & $\begin{array}{r}-.451 \\
.057\end{array}$ & $\begin{array}{l}.655 \\
.955\end{array}$ \\
\hline
\end{tabular}

Sumber: Output SPSS versi 20 data diolah (2019)

Tabel diatas, dapat diketahui bahwa nilai signifikan dari variabel X (anggaran kas) adalah 0,955 diatas $0,05>(0,05)$. Hal ini dapat disimpulkan dari tabel diatas bahwa Likuiditas pada perusahaan property dan real estate yang terdaftar di Jakarta Islamic Index (JII) tahun 2015-2017 tidak dipengaruhi oleh Anggaran Kas dikarenakan nilai signifikan dari variabel X (anggaran kas) adalah 0,955 diatas 0,05 (> 0,05). Selain melihat dari nilai signifikansinya, dapat pula dilihat dari $t$ hitungnya, dengan membandingkan $t$ hitung dengan $t$ tabel. Sebagaimana tabel diatas $t$ hitung dari variabel $\mathrm{X}$ (Anggaran Kas) adalah 1,593. Untuk dapat mengetahui besarnya $t$ tabel, yaitu dengan melihat $\mathrm{a}=0,05$, jumlah sampel dikurangi banyaknya variabel bebas $-1(33-1-1=$ 31), sehingga dapat diperoleh $t$ tabelnya sebesar 1,695 ( $t$ hitung 1,593 < t tabel 1,695). Sehingga dapat dikatakan bahwa likuiditas perusahaan yang terdaftar di JII tahun 20152017 tidak dipengaruhi oleh Anggaran Kas.

\section{Koefisien Determinasi $\left(\mathrm{R}^{2}\right)$}

Koefisien determinasi $\left(\mathrm{R}^{2}\right)$ berfungsi untuk mengetahui sejauh mana atau seberapa besar kemampuan variabel bebas (Anggaran Kas) terhadap variabel terikat (Likuiditas), hasil koefisien determinasi $\left(\mathrm{R}^{2}\right)$ dengan menggunakan SPSS versi 20 hasilnya adalah:

\section{Tabel 2}

Hasil Uji Koefisien Determinasi $\left(\mathbf{R}^{2}\right)$

\begin{tabular}{lrrrrr} 
Model & $\mathrm{R}$ & R Square & $\begin{array}{c}\text { Adjusted R } \\
\text { Square }\end{array}$ & $\begin{array}{c}\text { Std. Error of } \\
\text { the Estimate }\end{array}$ & Durbin-Watson \\
\hline 1 & $.010^{\mathrm{a}}$ & .000 & -.032 & .71815 & 2.252 \\
\hline
\end{tabular}

Sumber: Output SPSS versi 20 data diolah (2019)

Analisis data diatas dapat diketahui bahwa besarnya R Square adalah 0,000 atau 0\%. Hal ini menunjukan bahwa variabel independen X (Anggaran Kas) tidak memberikan kontribusi terhadap Likuiditas (QR) yaitu sebesar $0 \%$.

\section{Analisis Regresi Linier Sederhana}

Penelitian ini model regresi persamaan regresi sederhana yang disusun untuk mengetahui implikasi anggaran kas terhadap likuiditas pada perusahaan property dan real esrate di Jakarta Islamic Index (JII) Tahun 2015-2017 adalah:

$\mathrm{Y}=\mathrm{a}+\mathrm{bx}$

Analisis menggunakan program SPSS (Statistical Package For The Social Science) versi 20, diperoleh hasil sebagai berikut: 
Tabel 3

Hasil Analisis Regresi Linear Sederhana

\begin{tabular}{llrrrrr}
\hline Model & \multicolumn{2}{c}{$\begin{array}{c}\text { Unstandardized } \\
\text { Coefficients }\end{array}$} & $\begin{array}{c}\text { Standardized } \\
\text { Coefficients }\end{array}$ & T & Sig. \\
\cline { 3 - 6 } & & \multicolumn{1}{c}{ B } & Std. Error & Beta & & \\
\hline \multirow{2}{*}{1} & (Constant) & -.066 & .147 & & -.451 & .655 \\
& ANGGARAN KAS & $2.836 \mathrm{E}-015$ & .000 & .010 & .057 & .955 \\
\hline
\end{tabular}

Sumber: Output SPSS versi 20 data diolah (2019)

Analisis regresi linier sederhana pada tabel diatas diperoleh koefisien variabel anggaran kas $=2,836 \times 10^{-15}(\mathrm{X})$ serta konstanta (a) sebesar -0.066 sehingga model persamaan regresi linier sederhana yang diperoleh dalam penelitian ini adalah sebagai berikut:

$\mathrm{Y}=-0,066+\left(2,836 \times 10^{-15}\right) \mathrm{X} 1$

Model persamaan regresi linear diatas dapat diinterpretasikan sebagai berikut: $\mathrm{a}=-0,066$, dimana nilai konstanta likuiditas sebesar -0,066 menunjukan jika variabel $\mathrm{X}$ sama dengan nol (tidak dipertimbangkan), maka likuiditas (QR) sebesar -0,066 satuan. $\mathrm{b}=2,836 \times 10^{-15}$ dapat diartikan bahwa besarnya koefisien variabel anggaran kas bertanda positif $\left(2,836 \times 10^{-15}\right)$ mengindikasikan bahwa anggaran kas naik 1 , maka skor likuiditas naik sebesar 2,836×10-15 satuan.

\section{PENUTUP}

Berdasarkan dari hasil pembahasan, analisis data, dan pengujian hipotesis tentang "Pengaruh Anggaran Kas Terhadap Tingkat Likuiditas pada Perusahaan Property dan Real Estate di Jakarta Islamic Index (JII) Periode 2105-2017", maka dapat ditarik kesimpulan sebagai berikut:

1. Berdasarkan hasil analisis Uji $\mathrm{T}$ menandakan tidak terdapat pengaruh yang signifikan anggaran kas terhadap likuiditas pada perusahaan property dan real estate yang terdaftar di JII tahun 2015-2017, terbukti dengan melihat hasil Uji-t bahwa menunjukkan $t$ hitung sebesar 1,593 dengan nilai signifikansi 0,000 dan $t$ tabel 1,695. Karena 1,593 < 1,695 dan nilai signifikansi 0,955 > 0,05 sehingga Ha ditolak (H0 diterima). Hal ini menunjukkan bahwa anggaran kas tidak ada pengaruh yang signifikan terhadap likuiditas (Quick Ratio) pada perusahaan Property dan Real Estate di JII tahun 2015-2017.

2. Hasil koefisen determinasi $\left(\mathrm{R}^{2}\right)$ pada kolom $\mathrm{R}$ Square sebesar 0,00 artinya bahwa pengaruh anggaran kas terhadap likuiditas pada perusahaan property dan real estate yang terdaftar di JII tahun 2015-2017 tidak memberikan kontribusi atau sebesar $0 \%$.

\section{DAFTAR PUSTAKA}

Anang Fakhroji. Pengantar Manajemen Keuangan, Klanten : Yayasan Humaniora, 2010 Evan Asnaini,Stiawan dan Windi Asriani, Manajemen Keuangan, Yogyakarta: Teras,2012 Furqon, Statistika Terapan untuk Penelitian, Bandung: Alfabeta 2013 
Harahap Sofyan Safry. Analisi Kritis atas Laporan Keuangan,Jakarta: RajaGrafindo Persada, 2007

Mudrajad Kuncoro, Metode Kuantitatif teori dan aplikasi untuk bisnis dan ekonomi, Yogyakarta: sekolah tinggi ilmu manajemen YKPN, 2011

Muhamad, Manajemen Keuangan Syari'ah Analisis Fiqh dan Keuangan, Yogyakarta: UPP STIM YKPN,2016

Nafarin M. Penganggaran Perusahaan Edisi 3, Jakarta: Salemba Empat,2017

Nachrowi Djalal. Pendekatan Populer dan Praktis Ekonometrika untuk analisis ekonomi dan keuangan. Jakarta: Fakultas Ekonomi Universitas Indonesia. 2006

Prawironegoro Darsono, Ari Purwanto. Penganggaran Perusahaan Edisi 2. Jakarta: Mitra Wacana Media,2010

Simamora, Bilson, Riset Pemasaran, Falsafah,, Teori dan Aplikasi. Jakarta: PT Gramedia Pustaka Utama, 2004.

Sumarsono Sonny, Metode Riset Sumber Daya Manusia Yogyakarta: Graha Ilmu, 2004

Syahrial Dermawan. Djahotman Purba, Analisis Laporan Keuangan. Jakarta : Mitra Wacana Media,2013

Supangat Andi, STATISTIKA : Dalam Kajian Deskriptif, Inferensi, dan Nonparametrik. Jakarta : Prenadamedia Group, 2007

Sugiono. Statistika untuk penelitian, Bandung : Alfabeta, 2015

Sumarsan Thomas. Sistem Pengendalian Manajemen: konsep aplikasi dan pengukuran kinerja. Jakarta: Indeks, 2010

Sujarweni V. Wiratna ; Poly Endrayanto. Statistika Untuk Penelitian, Yogyakarta: Graha Ilmu, 2012

Shim Jae k, joel g. siegel. Budgeting, Jakarta: Erlangga, 2000

Sugiyono, Metode Penelitian Administrasi. Bandung: Alfabeta, 2016

Tim Penyusun Pedoman Penulisan Karya ilmiah, Pedoman Penulisan Karya Ilmiah : Pamekasan: STAIN Pamekasan, 2015

Amar Siti Salama, Noven Andriwiyono "Analisis Penggunaan Anggaran Kas Sebagai Alat Perencanaan dan Pengendalian untuk Meningkatkan Likuiditas Pada CV. Graha Tirta Pamekasan (Universitas Madura). Jurnal manajemen \& kewirausahaan, Vol 2 No. 18 november 2014 (diakses pada tanggal 20 april 2018)

Astuti, Analisis Faktor-Faktor Yang Mempengaruhi Likuiditas Perusahaan, Jurnal Manajemen dan Akuntansi No 11 Vol V (diakses pada tanggal 24 februari 2019)

Basri Ramlah. "Analisis Penyusunan Anggaran dan Laporan Realisasi Anggaran pada BPM-PD Provinsi Sulawesi Utara. ( Fakultas Ekonomi dan Bisnis Jurusan Akuntansi Universitas Sam Ratulangi Manado, Vol 1 No 4 Desember 2013. (diakses pada tanggal 19 april 2018)

Basori Rodi Khoirul ; Moch Dulkirom Ar ; Devi Farah Azizah, Analisis Perencanaan Budget Kas dalam Upaya Menjaga Tingkat Likuiditas Usaha (studi kasus pada koperasi SAE Pujon Periode 2013-2017), Jurnal Administrasi Bisnis (JAB) Vol 45 No1 April 2017 (diakses pada tanggal 15 september 2018)

Christine Debbie, Nike Ernawati."Penyusunan dan Realisasi Anggaran Kas Pada Koperasi Pegawai Telekom (KOPEGTEL) KANTOR DIVRE III BANDUNG, jurnal perkembangan peran akuntansi dalam bisnis yang professional, Vol 06 No 01, 27 maret (diakses pada tanggal 20 april 2018)

Febby Febiola Adyana Poetri "Pengaruh Anggaran Kas terhadap Likuiditas serta Dampaknya terhadap Laba Operasional pada PT. BPR Pola Dana Tasikmalaya 
(jurnal Akuntansi Fakultas Ekonomi Universitas Siliwangi Tasikmalaya), (diakses pada tanggal 20 April 2018)

Irwandi Maulana, Analisis Anggaran Kas sebagai Alat Perencanaan dan Pengendalian pada Koperasi Kopdit Rukun Palembang, jurnal akuntansi politeknik Sekayu, Vol 3, No 2, September 2015 (diakses pada tanggal 19 april 2018)

Nurfadillah Suci Siti. Pengaruh Anggaran Kas sebagai Alat Perencanaan dan Alat Pengendalian Terhadap Tingkat Likuiditas Pada Koperasi Bina Raharja Kuningan KCP Luragung. (Skripsi Fakultas syariah dan ekonomi islam IAIN Syekh Nurjati Cirebon) (diakses pada tanggal 19 april 2018)

Septiyani Eni, Siti Ragil Handayani, Muhammad Saifi"Analisis Budget Kas dalam Meningkatkan Likuiditas dan Profitabilitas Perusahaan Kacang Tulungagung (Fakultas ilmu administrasi Universitas Brawijaya Malang), (diakses pada tanggal 19 april 2018)

Setiawan, Dwi Endah Kursini, Ekonometrika. Yogyakarta: ANDI, 2010.

Sugiono Puspitasari Lisa ; Y Jogi Christiawan, Analisa Faktor yang Mempengaruhi Likuiditas Pada Industri Ritel yang Terdaftar Pada Bursa Efek Indonesia Tahun 2007-2012, Jurnal Business Accounting Review, Vol. I No 2 2013, (diakses pada tanggal 24 februari 2019)

Suartini Tini, "Pengaruh Anggaran Kas Terhadap Tingkat Likuiditas pada PD. Kebersihan Kota Bandung (Skripsi Fakultas ekonomi Universitas Komputer Indonesia Bandung, 2005) (diakses pada tanggal 7 oktober 2018)

https:www.sahamok.com/beda-real-estate-dengan-properti diakses pada tanggal 25 oktober 2018 jam : 09.00

https://id.m.wikipedia.org/wiki/Jakarta islamic indec diakses tanggal 5 Maret 2019 jam : 19.00

htpps://sbm.binus.ac.id/2015/11/20/uji-asumsi-klasik-uji-heteroskedastisitas.

Diakses tanggal 5 April 2019 jam : 19.00

https://www.kompasiana.com/andyan/5816f2d2bc93735c0e56fbee/prinsip-arus-kaskeluarga-islami-menurut-ad-dimasyqi Diakses pada tanggal 16 April 2019 jam : 20.00 